\title{
A kárpátaljai magyar kisebbség nyelvmegtartásáról és gazdasági életképességéről a nyelvi tájkép tükrében
}

\author{
CSERNICSKÓ ISTVÁN ${ }^{1}$
}

\begin{abstract}
ABSZTRAKT
A tanulmány nyelv és gazdaság összefüggésében vizsgálja Kárpátalja jellemzően magyarok lakta részeinek nyelvi tájképét. Azt mutatjuk be, hogyan jelenik meg a területen a nagy presztízzsel rendelkezó világnyelv, az angol, illetve az egykori Szovjetunió közvetító nyelve, az orosz. Bemutatjuk, hogy a gazdasági realitások miképp írhatják felül a kisebbségi közösség nacionalizmusát, illetve utalunk arra, hogy a nemzeti kisebbség nyelvmegtartását támogató nyelvpolitika nem lehet sikeres, ha nem jár együtt a gazdaság fejlesztésével. Hipotézisünk szerint ha többnyelvü környezetben javítani szeretnénk a kárpátaljai magyarok gazdasági helyzetén, akkor nyelvoktatás az egyik olyan terület, ahová feltétlenül szükséges invesztálni.

KULCSSZAVAK: nyelv és gazdaság, nyelvi tájkép, nyelvmegtartás, angol nyelv, orosz nyelv, Kárpátalja
\end{abstract}

\section{ABSTRACT}

\section{Maintenance of minority languages and economic viability of minorities} in the mirror of the Transcarpathian linguistic landscape

The study examines the linguistic landscape of the territories of Transcarpathia (Ukraine) which are mostly inhabited by Hungarians in the context of language and economy. It will be presented how economically prestigious world languages, English and Russian are displayed in this region. We show that economic realities suppress the nationalism of the minority int he linguistic landscape. We note that the language policy in support of the language maintenance of the national minority can not be successful if it is not related to the development of the economy. If we want to improve the economic situation of the Hungarians of Transcarpathia in a multilingual environment, the teaching of languages is one of the areas where it is necessary to invest.

KEYWORDS: language and economy, linguistic landscape, language maintenance, English languale, Russian language, Transcarpathia

${ }^{1}$ II. Rákóczi Ferenc Kárpátaljai Magyar Főiskola Hodinka Antal Nyelvészeti Központ, igazgató és Pannon Egyetem, egyetemi docens. 


\section{TEMATIKUS TANULMÁNYOK - Kárpátalja társadalma}

\section{Bevezetés}

A Hodinka Antal Nyelvészeti Kutatóközpontban a régió nyelvi tájképének dokumentálása, elemzése abból a nyelvpolitikai kutatási programból nőtt ki, amelynek kiindulási pontja, hogy a nyelvi tájkép a nyelvpolitika egyik megjelenési formája (Dal Negro 2009: 206, Shohamy 2015: 168, Spolsky 2004: 5), amely szoros összefüggésben van a nyelvi ideológiákkal (Bartha - Laihonen - Szabó 2015: 216, Blommaert 2006: 244). A kutatóközpont archívumában összegyűlt fotóanyag lehetőséget teremt arra, hogy a ma Kárpátaljának nevezett vidék nyelvi tájképét számos szempontból elemezzük. Az alábbiakban nyelv és gazdaság összefüggésében tárgyalom Kárpátalja jellemzően magyarok lakta részeinek nyelvi tájképét. Azt mutatom be, hogyan jelenik meg ezen a területen két világnyelv: az angol és az orosz. Bemutatom továbbá, hogy mindez milyen összefüggésben van a kárpátaljai magyar nemzetrész nyelvmegtartási törekvéseivel és gazdasági pozícióival.

Kárpátalja magyar közössége az 1980-as évek vége óta törekszik arra, hogy a magyar nyelv egyre több funkcióban legyen használatos a vidéken. A régió magyarok lakta sávjában ma már teljesen természetes, hogy a magyar - természetesen más nyelvek mellett - hangsúlyosan jelen van a feliratokon (Beregszászi 2005, Laihonen - Csernicskó 2017, Hires-László 2015, Karmacsi 2014a, 2014b, Tóth 2014a, 2014b). Az utóbbi két-három évben azonban ismét egyre több nem magyar nyelvü felirat, kiírás jelent meg a kárpátaljai magyar nyelvterület szimbolikus terében. Mindez annak ellenére történik, hogy a 2012-ben elfogadott és máig hatályos ukrán nyelvtörvény a korábbiakhoz képest szélesebb jogokat biztosít a magyar nyelv használatára, a nyelvi tájképben is (Tóth - Csernicskó 2014). Tanulmányomban a nyelvi tájképet nem kvantitatív, hanem kvalitatív szempontból elemzem, de utalok a téma kvantitatív szempontú elemzését elvégző tanulmányokra.

\section{Az angol nyelv megjelenése Kárpátalja magyarok lakta területein}

Az angol nyelv terjedésére a posztszovjet térség államaiban (s ezen belül Ukrajnában) több kutató felhívta a figyelmet (Bilaniuk 2005, Hornberger 2003, House 2003). Mások (például Bever 2010, Oliynyk 2013) arra is rámutattak, hogy az angol nyelv Ukrajna nyelvi tájképében is egyre markánsabban van jelen.

House (2003: 561) bemutatja, hogy a második világháború után új utakon elinduló Németországban az angol a demokratikus állam szimbólumává vált, és segített az embereknek elfeledni a múltat. A szerző szerint a Szovjetunió széthullása után Kelet-Európa posztszovjet államaiban az angol hasonló funkciókat tölt be, és egyben segédeszköze az orosz mint korábbi lingua franca kiszorításához (House 2003: 561). Pavlenko (2009: 258) összeveti az angol terjedését a kelet-európai országokban és a szovjet utódállamokban, és arra a következtetésre jut, hogy a hasonlóságok mellett különbségek is vannak e folyamatban. A terjedőben lévő angol mindenütt magas 


\section{TEMATIKUS TANULMÁNYOK - Kárpátalja társadalma}

presztízsű; az innováció, a globalizáció és a nyugati értékek nyelveként jelenik meg. Az egykori Szovjetunió államaiban azonban az angol mindezek mellett a szovjet totalitárius rezsimmel asszociálódó orosz nyelv kiszorításával is együtt jár. Miközben a volt keleti blokkban az angol a helyi nyelvek mellé lépett be a nyelvek piacára, a volt szovjet birodalomból kiszakadt országokban a globális világnyelv verseng az oroszszal a magas presztízsű lingua franca pozíciójáért (Pavlenko 2009: 258). Egy másik tanulmányában bemutatja, hogy az ukrán nyelvpolitika célja a nyelvi tájkép ukránosítása, amibe az orosz-ukrán kétnyelvűség helyére lépő ukrán-angol kétnyelvűség is belefér (Pavlenko 2012: 53). A posztszovjet térségben az orosz így fokozatosan átadja a helyét a nyilvános térben a globális világnyelvnek, az angolnak.

Hornberger (2003: 2) úgy látja, hogy az 1991-ben függetlenné vált és a helyét, identitását kereső Ukrajnában a helyi, a nemzeti és a globális diskurzusok átfedik egymást, rivalizálnak egymással, és ez a versengés a nyelvi tájképben is érzékelhető. Mindez úgy jelenik meg a felszínen (azaz a nyilvános térben), mint az ukrán, az orosz és az angol nyelv közötti vetélkedés, ami egyben a cirill és a latin betüs feliratok szintjén is folyik. Kelet-Ukrajna nagyvárosainak nyelvi tájképét elemezve Bever (2010: 211-215) arra következtet, hogy az elsősorban orosz nyelvű régió nyelvi tájképében egyre gyakrabban megjelenő angol nyelv (és vele a latin betűs írás) egyfajta kompromisszum az ukránosítani szándékozó központi hatalom és az orosz nyelv dominanciáját fenntartani szándékozó helyi lakosság egymással szemben álló nyelvi ideológiái között. Az angol terjedését Ukrajnában egyrészt a globalizáció hatásával, másrészt pedig a nemzetközi piac ukrajnai terjeszkedésével, a multik és világmárkák megjelenésével magyarázza (Bever 2010: 213-214). Négy ukrajnai nagyváros (Kijev, Dnyipro[petrovszk] ${ }^{2}$ Lviv/Lemberg és Odessza) nyelvi tájképét elemző munkájában L'nyavskiy-Ekelund (2016: 93) arra a következtetésre jut, hogy az angol arrafelé „a hatalom, a presztízs, a globalizáció és a nyugati világhoz tartozás nyelve”, majd leszögezi, hogy „a kapitalizmus Ukrajnában már nemcsak oroszul beszél, mint korábban", hanem sokkal inkább angolul (L'nyavskiy-Ekelund 2016: 96).

Az orosz kiírásokat fokozatosan felváltó angol nyelvű feliratok kapcsán egyetlen elemző sem figyelt fel arra a jelenségre, hogy miközben az ukrajnai nemzetépítés egyik kiemelt projektje a minél erősebb pozíciók kivívása az ukrán nyelv számára, elsősorban az orosz nyelvvel szemben, az ukrán hatóságokat nem aggasztja az angol egyre erősebb térhódítása Ukrajnában. Ebből is látszik, hogy a nemzetépítési folyamatban elsősorban az orosz nyelvvel és kultúrával, illetve a szomszédos Oroszországgal szemben folyik az ukrán identitás meghatározása és megerősítése. Ebben a folyamatban az angol nem a veszélyeztetettnek tekintett ukrán nyelvet fenyegető

${ }^{2}$ Dnyipropetrovszk (ukránul: Дніпропетровськ) városát az ukrajnai úgynevezett dekommunizációs törvény alapján 2016. február 4-én Dnyipro (ukránul: Дніпро) névre nevezte át az ukrán parlament (Fedinec-Csernicskó 2016: 89-90). 


\section{TEMATIKUS TANULMÁNYOK - Kárpátalja társadalma}

globális világnyelvként, hanem a nyugati integráció és a szovjet világból való kiszakadás egyik szimbólumaként jelenik meg.

Laihonen egy magyar többségű és egy vegyes lakosságú kárpátaljai falu nyelvi tájképét elemezve azt tapasztalta, hogy Kaszonyban az összes felirat 8,03\%-án jelent meg az angol nyelv, Visken pedig 9,78\%-án (Laihonen - Csernicskó 2017). Az angol nyelvű kiírások beregszászi jelenlétét Hires-László Kornélia (2015) rögzítette először. A kutató összesen 1172 fényképet készített a város központjában, ezek közül 73 feliraton volt jelen az angol nyelv. Ez az összes felvétel 6,2\%-a; 16 felirat (az összes kiírás 1,4\%-a) egynyelvű angol volt (Hires-László 2015: 167).

A kisebbségi nyelvek fenntartásában a nyelvet használó közösség gazdasági életképessége meghatározó (Da Silva - Heller 2009). Kárpátalja iparilag fejletlen vidék, a jellemzően hegyvidéki környezet miatt kevés a művelhető földterület is. A régió gazdasági elmaradottságából és infrastrukturális lemaradásából adódóan a munkahelyek száma is kevés. Egyre többen látnak azonban kitörési pontot a turizmusban (Berghauer 2012). A turistákat alapvetően két irányból várja Kárpátalja: Ukrajna belső területeiről és a szomszédos országokból. Ukrajnából télen a Kárpátok sípályái, nyáron a hegyek természeti szépségei, illetve a termálfürdők vonzzák az utazókat. Magyarországról elsősorban a régió magyar vonatkozású történelmi emlékhelyei, a nemzeti örökség turizmus (Feischmidt 2008: 122) miatt utaznak ide sokan. Miután 2014 márciusában Ukrajna gyakorlatilag elveszítette legkedveltebb nyári üdülőhelyét, az Oroszország által annektált Krím-félszigetet, és az ország keleti végein fegyveres konfliktus dúl, Kárpátalja turisztikai vonzereje tovább növekszik; elsősorban a belföldi turistaforgalom növekedett meg (Csernicskó - Laihonen 2016, Karmacsi 2017). A 2012-es ukrán-lengyel közös rendezésű labdarúgó Európa-bajnokságtól is azt várták, hogy fellendíti a turizmust. A nemzetközi sportesemény előtt számos angol nyelvű vagy angol nyelvű szöveget is tartalmazó felirat, információs tábla, szóróanyag jelent meg az egész ország területén, így Kárpátalján is. Ezek a feliratok nem a helyi lakosságnak, hanem a régión átutazó, az ukrán és orosz nyelvet nem ismerő külföldieknek szóltak.

Az angol kiírások terjedése Kárpátalján a globalizációval is összefügg. Egyre több nemzetközi cég, márka, brend jelenik meg a régióban. Blommaert (2010: 24) ezt a fajta nemzetköziséget a „McDonaldization” (McDonaldizáció) terminussal nevezi meg, s ez annak ellenére jellemző Kárpátaljára is, hogy a régióban egyetlen McDonald's sem müködik napjainkban. Az angol viszont a globális üzlet és kereskedelem, valamint a nemzetközi populáris kultúra révén egyre gyakrabban jelenik meg a kárpátaljai nyelvi tájképben (Csernicskó - Laihonen 2016: 21-22). Ezt jelzi, hogy Kárpátalja városaiban - így Beregszászban is - az angol nyelvü feliratok az utcakép szerves és természetes részeivé váltak. Az angol nemcsak a reklámfeliratokon tűnik fel, hanem például hirdetéseken, szolgáltatásokat kínáló tájékoztató táblákon is.

A turistákat célozza meg például az a kiírás, amely az 1. ábrán látható. A tábla ukrán és angol nyelven kínál szálláshelyeket a Beregszászba érkezők számára. Az 


\section{TEMATIKUS TANULMÁNYOK - Kárpátalja társadalma}

ukrán szövegek közé ékelt rooms for rent angol nyelvű szöveg funkciója valószínúleg az információ közlésén túl az, hogy a nyugati életszínvonallal kapcsolatos asszociációkat hívjon elő.

\section{1. ábra: Szálláshelyeket ukrán és angol nyelven hirdető plakát Beregszászban}

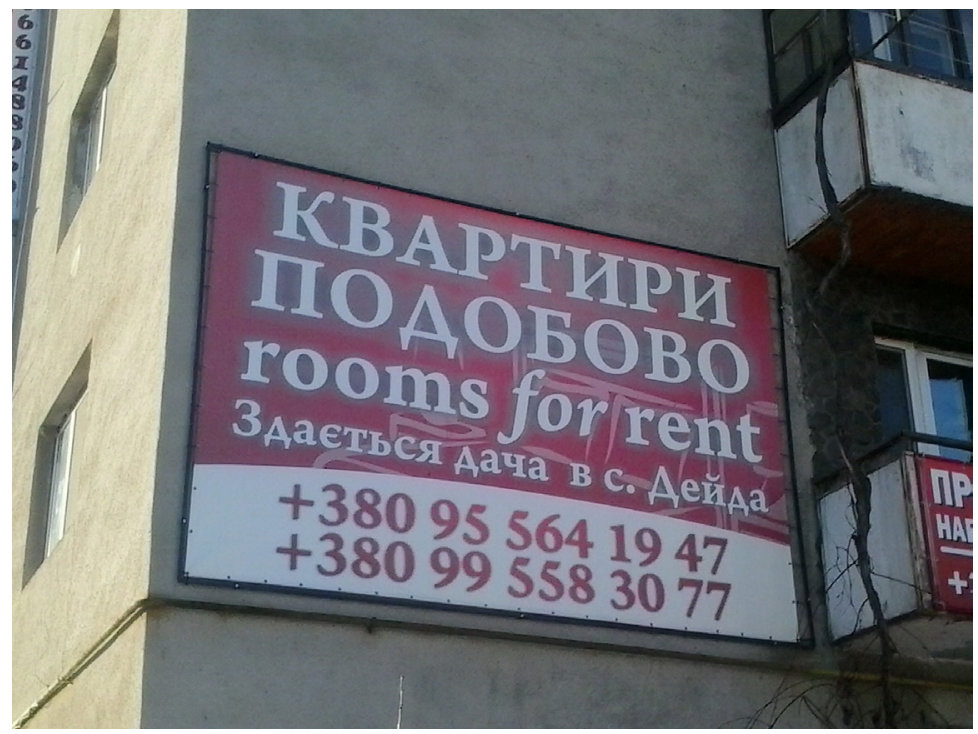

Forrás: A Hodinka Antal Nyelvészeti Kutatóközpont archívuma

Bever (2010: 53) szerint a kelet-ukrajnai városok bankjainak, pénzügyi szolgáltatást nyújtó intézményeinek feliratain az angol nyelv megjelenése az angol nyelvü nemzetközi pénzpiac gazdasági presztízsét és megbízhatóságát jelképezi. Feltételezhetjük, hogy az információs cél mellett Kárpátalján hasonló okokból jelenik meg a globális angol a pénzváltók kirakatában. A beregszászi pénzváltók homlokzatán is látható az angol nyelv az ukrán és a magyar mellett.

Kárpátalját Ukrajnán belül - többek között azért, mert az Európai Unió négy tagállamával, Lengyelországgal, Szlovákiával és Magyarországgal határos - az ország nyugati kapujaként is emlegetik. Beregszász város - amelytől nyolc kilométernyire található az Asztély-Beregsurány ukrán-magyar nemzetközi határátkelő - európaiságát, nyitottságát szimbolizálják a városban több helyen látható angol kiírások, valamint az Európai Unió szimbólumainak elhelyezése a város központi épületein. A kisváros fóterének egyik végén az egykori zsinagóga, ma a járási kultúrház épülete áll (2. ábra). A homlokzat bal oldalán a kék-sárga ukrán, jobb oldalán a piros-fehérzöld magyar lobogó látható, középen pedig az Európai Unió zászlaja legfelül a város 


\section{TEMATIKUS TANULMÁNYOK - Kárpátalja társadalma}

oroszlános címerével. Az EU lobogója itt egy olyan ország városának főterén jelenik meg, amely nem tagja az Uniónak.

\section{2. ábra. Az EU jelképe Beregszász központi terén}

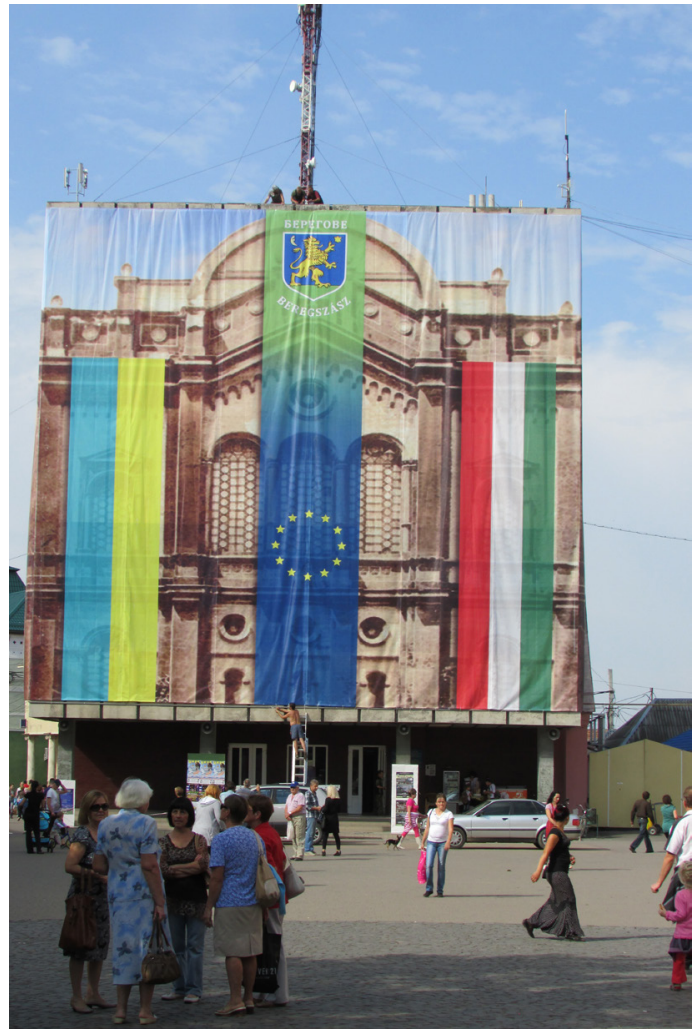

Forrás: A Hodinka Antal Nyelvészeti Kutatóközpont archívuma

A nyugati világ és kapitalizmus elől évtizedeken át elzárt egykori szovjet régióban a magas presztízsű globális lingua franca hirtelen megjelenése nem járt együtt a magas szintű angol nyelvtudás széles körűvé válásával. Pavlenko (2009: 258) beszámol arról, hogy a posztszovjet államok nyelvi tájképében gyakran az angol nem-sztenderd, „helyi” változata jelenik meg. Blommaert (2010: 103) a globalizáció révén terjedő, hiányos nyelvtudásból fakadó angol jellegzetességeit a "truncated repertoire" (csonka repertoár) terminussal jelöli. A sztenderd angolhoz mérve hibás graffitit mutat be például a kárpátaljai Mezőkaszonyból Csernicskó és Laihonen (2016: 21). A 3. ábrán látható felirat is csak ebben a kontextusban értelmezhető. A Beregszász központjában lévő kétnyelvű útjelző tábla cirill betűs ukrán és latin betűs (talán) 


\section{TEMATIKUS TANULMÁNYOK - Kárpátalja társadalma}

angol nyelvű feliratokat tartalmaz. A helyi, cirill betűt olvasni tudó és az ukrajnai kulturális viszonyokat ismerő utazó azt olvashatja le a tábláról, hogy а „Лужанка/ Luzhanka” határátkelő egyenesen 7 km-re, а „Вілок/Vilok” és а „Дяково/Dyakovo” határátkelő pedig balra 23, illetve 43 km-re található. Az ukrajnai valóságot nem ismerő gépjárművezető azonban jó eséllyel nem tudja, hogy az idézőjelek között megjelenő szavak itt nem(csak) településnevet jelölnek, hanem a nemzetközi határátkelő neveként jelennek meg a táblán. Mint ahogyan azt sem sokan tudják, hogy a tábla latin betűs részén a „Luzhanka”, „Vilok” és „Dyakovo” előtt egyaránt látható KPP az ukrán Контро́льно-пропускниий пункт (ellenőrző pont) rövidítése, ami a közlekedési útmutató táblán a vám- és útlevél-ellenőrzési helyet is jelentő nemzetközi határátkelőt jelöli. Hiába van tehát a cirill betűs ukrán alatt latin betűs angol nyelvú (latin betűs) felirat is, a keleti szláv nyelvekben és kultúrában idegenül mozgó utazók könnyen eltévedhetnek: a KPP rövidítés értelmezhetetlen számukra.

3. ábra. Nehezen dekódolható latin betűs felirat egy nemzetközi útjelző táblán Beregszász központjában

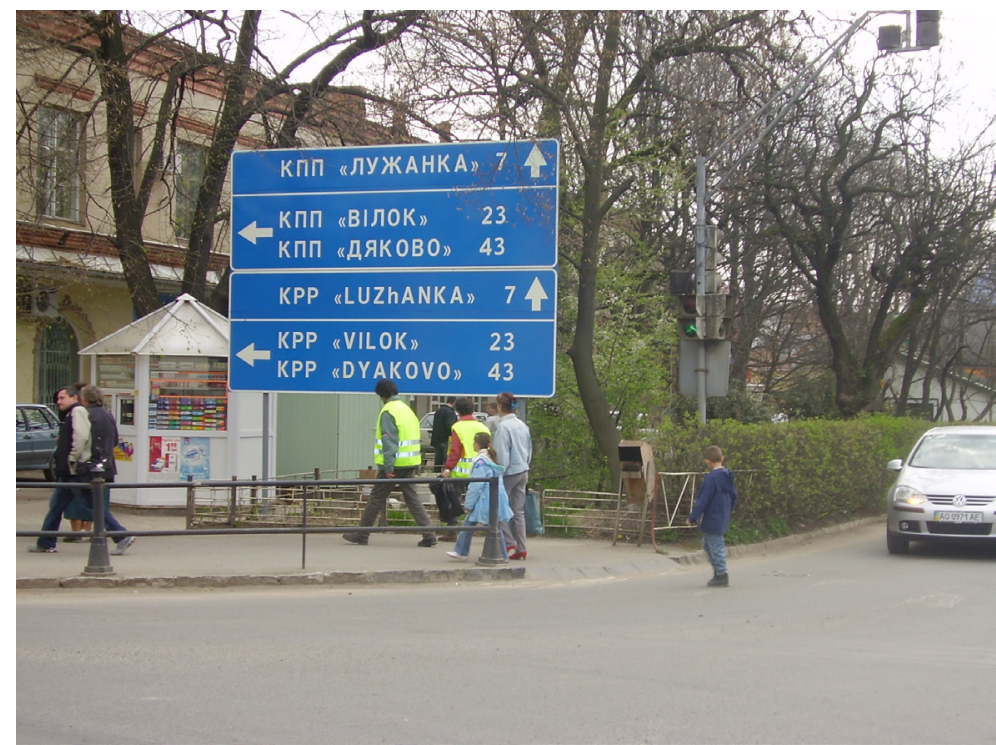

Forrás: A Hodinka Antal Nyelvészeti Kutatóközpont archívuma

Az angol nyelv a régió egyik legjelentősebb turisztikai desztinációja, a kaszonyi fürdő nyelvi tájképében is megjelenik. Az elsősorban ukrajnai vendégeket vonzó termálfürdő és szálloda területén látható kiírások legnagyobb része ukrán, ritkábban kétnyelvű (ukrán-magyar). Az angol nyelvű feliratok kevéssé funkcionális jellegűek, megéretésüket rendszerint vagy ukrán nyelvű szöveg, vagy az angol szöveg fölött 


\section{TEMATIKUS TANULMÁNYOK - Kárpátalja társadalma}

látható piktogram segíti. Az angol nyelv megjelenése azt üzeni a kaszonyi termálfürdő vendégeinek, hogy a hely modern, globális és nyugati is egyben. A nyugati világra asszociáló angol nyelv azt hivatott jelképezni az ukrajnai turista számára, hogy anélkül jutott el egy európai színvonalú helyre, hogy végigjárta volna a schengeni vízum beszerzésének drága és időigényes útját (Csernicskó - Laihonen 2016). Ahogyan Pavlenko (2009: 285) fogalmaz, az ilyen angol nyelvű feliratok elsődleges funkciója, hogy „nemzetközi aurát” biztosítsanak.

A turizmushoz kapcsolódóan néhány kárpátaljai étteremben már angol nyelven is olvasható az étlap kínálata. Ahogyan a 4. ábrán látható, a lacipecsenye igazi nemzetközi étel: ukrán, orosz és angol nyelven is ugyanígy nevezik ezt a fogást.

4. ábra. Egy ungvári étterem négynyelvű étlapja

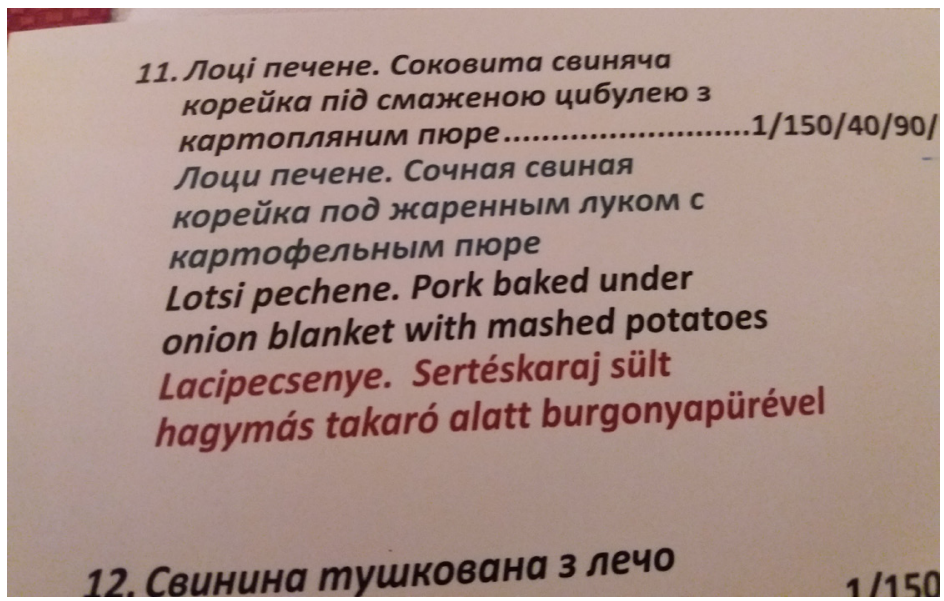

Forrás: A Hodinka Antal Nyelvészeti Kutatóközpont archívuma

\section{Az orosz nyelv Kárpátalja magyarok lakta sávjában}

Az orosz - mint az egykori Szovjetunió privilegizált nyelve - a kommunizmust építő birodalom széthullása után szinte azonnal elkezdett visszaszorulni az egykori szovjet érdekszférából (Pavlenko 2008: 282, L'nyavskiy-Ekelund 2016, Bátyi 2017) és Kárpátaljáról is. Jelenléte azonban ma is kimutatható a posztszovjet térségben (Muth 2015a, 2015b), így Ukrajnában (Pavlenko 2012: 46-47, Bever 2015), és Kárpátalja jelentős részben magyarok lakta településein is. Laihonen kutatása szerint Kaszonyban a közterületi feliratok 5,84\%-a, Visken 1,50\%-a volt orosz (Laihonen Csernicskó 2017). Beregszász nyelvi tájképét elemző tanulmányában Hires-László (2015: 167) az összesen rögzített 1172 fotó között 27 orosz nyelvüt talált; az összes 


\section{TEMATIKUS TANULMÁNYOK - Kárpátalja társadalma}

kiírás 2,3\%-án volt jelen az orosz nyelv a városban, az egynyelvű orosz szövegek száma 22 (1,9\%) volt.

Pavlenko (2009: 251) rámutat, hogy Ukrajnában nem mindig egyszerű eldönteni, hogy a nyilvános térben megjelenő orosz nyelv a nemzetek közötti érintkezés nyelveként, regionális lingua franca-ként, vagy pedig a helyben élő orosz ajkú közösség anyanyelveként látható. Az alábbiakban bemutatott példákból kiderül, hogy az orosz nyelvű szöveget (is) megjelenítő kiírások egy részére vonatkoztatható Pavlenko megállapítása, ám az orosz feliratok jelentős része egyik kategóriába sem sorolható: ezekkel a helyi magyar közösség tagjai a kívülről érkező, más nyelvű embereket próbálják megszólítani.

A Beregszászban és környékén látható orosz nyelvű feliratoknak egy része minden bizonnyal még a szovjet korszakból maradt meg. Tóth (2014a: 63) a Beregszászi járás két településének nyelvi tájképét elemezve rámutat, hogy bár a Szovjetunió már 1991 óta nem létezik, „a községek utcanévtáblái még mindig csak orosz nyelvűek”. Elemzéséből az is kiderül, hogy „a halábori kultúrház névtáblája még mindig orosz és magyar nyelvű, egy badalói épületen továbbra is látható a szovjet hadsereg emlékére felállított orosz és magyar nyelvű emléktábla. (...) A magasfeszültségre figyelmeztető táblák mindkét településen csak orosz nyelvűek" (Tóth 2014a: 62). Az ilyen jellegú orosz feliratok fennmaradását Pavlenko (2009: 257) úgy értelmezi, hogy az egykori gyarmatosító nyelve még sokáig használatban marad az egykori gyarmatokon.

A kaszonyi termálfürdő nyelvi tájképét elemző korábbi tanulmányunkban (Csernicskó - Laihonen 2016) bemutattuk, hogy a Kárpátalja magyarok lakta részeire érkező szláv turisták jelentős része az orosz nyelvet használja. Nem véletlen tehát, hogy az orosz nyelvű feliratok ismét elkezdtek megjelenni a régió nyelvi tájképében. Az orosz nyelvnek a turizmus általi (újra)megjelenése a posztszovjet térségben nem egyedi jelenség. Kutatók hasonlóról számolnak be a balti államokban (Marten et al. 2012, Muth 2015b, Pavlenko 2017a, Zabrodskaja 2016), illetve Magyarországon (Bátyi 2014). Ryazanova-Clarke (2014: 12) szerint az orosz nyelv ismét megfigyelhető terjedése Oroszországon kívül annak transznacionális gazdasági értékével magyarázható. Ukrajnában pedig „csaknem minden ukránnak, aki pénzt akar keresni, tudnia kell oroszul" (Rybka 2016). A posztszovjet térséghez tartozó Kárpátalján az orosz még mindig fontos nyelv.

Az orosz nyelv turisztikai hasznosságát jelzi az 5. ábra. A fotó a Beregszászi Járási Állami Közigazgatási Hivatal épülete előtt készült. Az épület alagsorában működő önkiszolgáló étterem egy utcai reklámtábláján egyik oldalon ukránul, a másikon orosz nyelven is hirdeti, hogy „gyorsan, finomat és olcsón” ebédelhet a hozzájuk betérő vendég. Az orosz nyelvű kiírás nyilvánvalóan nem az épületben dolgozó hivatalnokokat, nem is a városban élő, az ukrán és a magyar nyelvet az orosznál jobban ismerőket próbálja megszólítani, hanem a Beregszászba érkező turistákat. 


\section{TEMATIKUS TANULMÁNYOK - Kárpátalja társadalma}

5. ábra. Ukrán, illetve hátoldalán orosz nyelvű reklámtábla a Beregszászi Járási Állami Közigazgatási Hivatal épületében működő önkiszolgáló étterem előtt
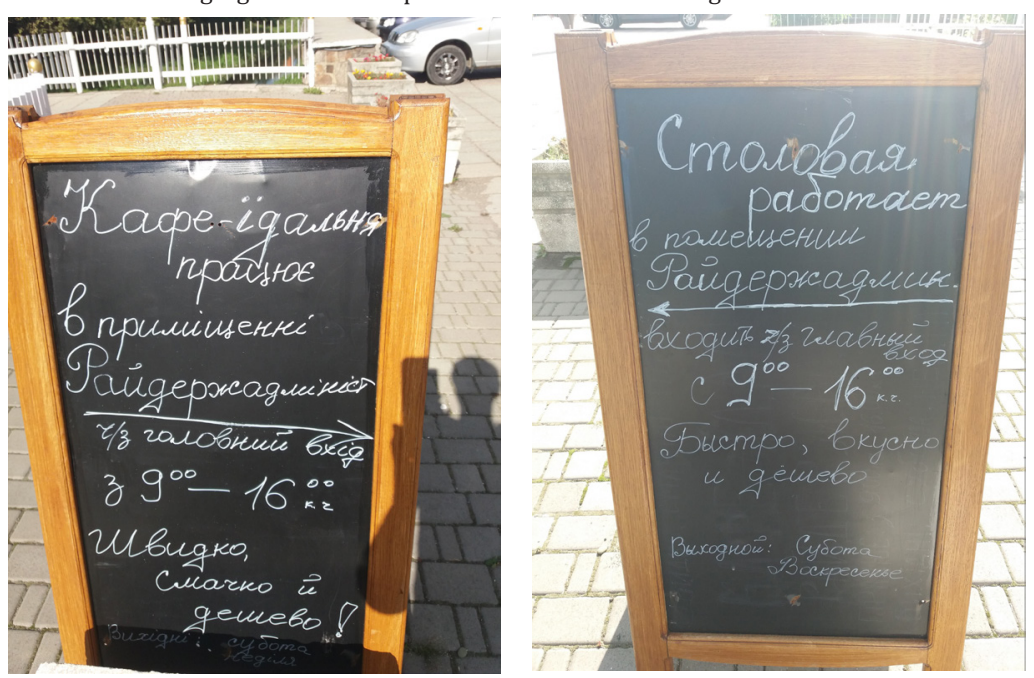

Forrás: A Hodinka Antal Nyelvészeti Kutatóközpont archívuma

Ukrajna függetlenné válása óta az orosz nyelvet már nem oktatják az iskolákban, így felnőtt egy generáció, amely nem feltétlenül ismeri a sztenderd oroszt. A 6. ábrán egy olyan kiírást láthatunk, amely - nagy valószínűséggel magyar anyanyelvű - fogalmazója hiányos orosz nyelvismeretéről tanúskodik. A kiírás fókuszában látható „Выдаётся” magyar kontaktushatás: a magyar 'kiadó' tükörfordítása. Az orosz nyelvű szövegben megjelenő „i” kötőszó viszont ukrán kontaktushatás: az orosz ábécében $i$ betű nincs, van ellenben az ukránban.

6. ábra. Sajátos helyesírással kihelyezett orosz nyelvű hirdetés Beregszászban

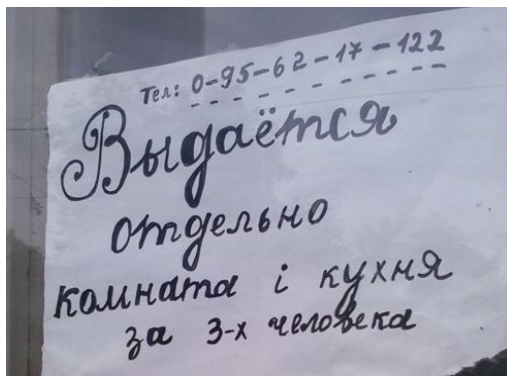

Forrás: A Hodinka Antal Nyelvészeti Kutatóközpont archívuma

Nagy valószínűséggel a nem sztenderd orosz feliratok is a Blommaert (2010) által „truncated repertoire”-nak nevezett jelenséghez sorolhatók. Pavlenko (2017b: 


\section{TEMATIKUS TANULMÁNYOK - Kárpátalja társadalma}

500) szerint az ilyen, hiányos orosz nyelvtudásról tanúskodó feliratok alapján olyan oroszul beszélőkre következtethetünk, akik a várható gazdasági előnyök kedvéért helyezték ki az orosz nyelvű táblákat. Pavlenko (2017b: 495) ezt a nyelvi igazodás (linguistic accommodation) terminussal jellemzi: a potenciális vásárló nyelvét próbálja használni az, aki szeretné az oroszul beszélőknek eladni áruját, szolgáltatását.

Egyik előadásában Zabrodskaja (2016) azt mutatta be, hogyan vált a szovjet múlttól elszakadni vágyó Észtországban az orosz előbb az ellenség nyelvévé, majd a kis független balti államba érkező gazdag és sokat költő orosz turisták miatt miként jelent meg újra a kiemelt turisztikai helyszíneken. Azt is elmondta azonban, hogy miután Oroszország 2014 tavaszán annektálta a Krímet, az ennek következtében bevezetett gazdasági és politikai szankciók, illetve az orosz rubel jelentős gyengülése miatt az Észtországba látogató orosz turisták száma a töredékére esett vissza, így az orosz ismét az észt függetlenséget fenyegető megszállók nyelve lett (Zabrodskaja 2016). Hasonló a helyzet Kárpátalján is. A Krím megszállása, illetve a kelet-ukrajnai konfliktus miatt Ukrajnában az ellenség nyelvévé kikiáltott orosz egyben a Kárpátaljára érkező és ide pénzt hozó turisták jelentős részének a nyelve is egyben.

Pavlenko (2017a) és Cabal-Guarro (2017) kognitív disszonanciaként jellemzi azt a helyzetet, ahol az orosz nyelv egyszerre jelent gazdasági erőforrást és kapcsolódik negatív politikai vagy más asszociációkkal. Ez a fajta kognitív disszonancia jelenik meg Kárpátalján is, hiszen - amint a fentiekben láthattuk - az orosz nyelv annak ellenére jelen van Kárpátalja nyelvi tájképében, hogy 2014 tavasza óta Ukrajnában az orosz nyelvet egyre gyakrabban azonosítják az agresszor Oroszországgal (lásd pl. Maszenko 2016). A gazdasági realitások azonban időnként felülírják, vagy legalábbis árnyalják a politikai érdekeket és a nemzeti érzelmeket. Ezt igazolja az is, hogy az angol és az orosz mellett természetesen államnyelven kínált szálláshely is akad bőven Kárpátalja magyarok lakta vidékein. Az ezeket reklámozó feliratok, kírások egy része ukrán-magyar kétnyelvü, de túlnyomó többségük csak ukrán nyelven jelenik meg, például a szintén főként magyarlakta Déda községben (7. ábra), vagy épp Nagybégányban, Zápszonyban és Kaszonyban is (Karmacsi 2017).

7. ábra. Ukrán nyelven szállást kínáló kiírások Déda községben

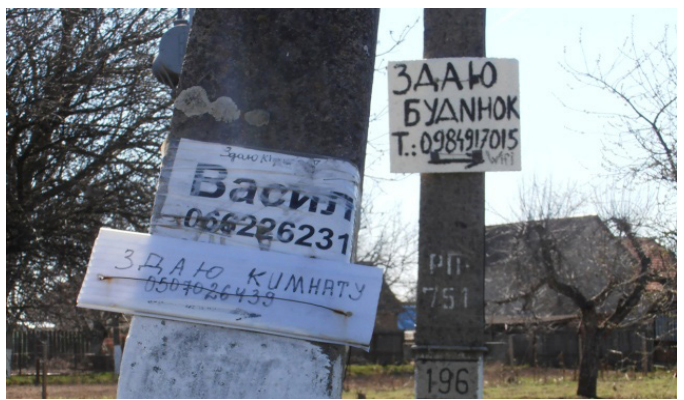

Forrás: A Hodinka Antal Nyelvészeti Kutatóközpont archívuma 


\section{TEMATIKUS TANULMÁNYOK - Kárpátalja társadalma}

\section{Diszkusszió}

Simonyi és Pisano (2011: 230) szerint a magyar többségű településen élő tipikus kárpátaljai magyar ember magyar tannyelvű iskolát végzett és ilyen intézményt választott gyermeke számára is, gyakran jár át Magyarországra bevásárolni, a magyar televízió adásait nézi, és családját hétvégén valamely magyarországi városba viszi moziba vagy kikapcsolódni. Az idézett szerzők azt is meggyőződéssel állítják, hogy ennek a tipikus kárpátaljai magyarnak az ukrán-magyar államhatár átlépése nem több adminisztratív rutinnál, és nem okoznak számukra semmilyen érzékelhető változást a feliratok, amelyek otthon is dominánsan magyar nyelvüek. Sokkal szembetűnőbb változást jelent az, amikor Ukrajna belsejébe (átkel a Kárpátokon) vagy a közeli Munkácsra utazik: ebben a szláv politikai térben és a feliratok tekintetében is a magyar nyelvű környezet láthatatlanná válik. Kárpátaljai ukrán kutatók szintén úgy vélik, hogy Kárpátalja déli, magyarok lakta sávjának nyelvi tájképe dominánsan magyar, és a magyar feliratok aránya felülmúlja az ukrán nyelvű kiírásokét (Belej 2012, Tarkanyij 2011). Elemzésünkből azonban egyértelműen kiderül, hogy az abszolút magyar domináns nyelvi tájkép csupán illúzió, még az egyébként abszolút magyar többségű településeken is, s ez így van nemcsak Kárpátalján, hanem Romániában, Szlovákiában, és a többi magyarlakta régióban is (lásd Laihonen - Csernicskó 2017, Lulic 2013, Satinská 2013, Szoták 2013, 2017a, 2017b stb.). A magyar nyelv mellett azonban nemcsak az államnyelv jelenik meg Kárpátalja városainak és magyar többségű falvainak nyelvi tájképében, hanem egyre gyakoribb, hogy az angol és/vagy az orosz nyelv is (újra) látható.

Burdick (2012: 2) szerint „a nyelvi tájkép kutatásának módszertana jól alkalmazható a nyelvek áruvá válásának tanulmányozása során, azoknak a tereknek a megismerésében, melyekben a nyelvek áruvá válnak”. Megfogalmazása szerint „,a piaci gyakorlatok a nyelvet közvetlenül alkalmazhatóvá teszik a munkaerőpiacon és a turizmusban" (Burdick 2012: 11-12). Nem véletlen, hogy Comaroff és Comaroff (2009) szerint a kisebbségi nyelvi közösségek újabban a gazdasági életképességért küzdenek a nemzetiségi és nyelvi jogok helyett. A nem domináns közösségek a megváltozott gazdasági viszonyok közepette a politikai szempontok mellett/helyett a profittermelés aspektusából értékelik át és alkotják újra a saját nyelvükhöz, nyelvváltozataikhoz fűződő viszonyt és stratégiát (Kelly-Holmes - Pietikäinen 2014: 522). A mai Kárpátalján hasonló jelenség figyelhető meg.

\section{Társadalmi implikációk}

A nyelvtudás (legyen szó akár a magyar vagy az ukrán, akár az orosz, de különösen az angol nyelvről) jelentősen erősíti a kárpátaljai magyarok munkaerőpiaci pozícióit, és növeli mobilitási esélyeit, lehetőségeit. Mindez azonban fordítva is igaz: a 


\section{TEMATIKUS TANULMÁNYOK - Kárpátalja társadalma}

nyelvtudás hiánya nagy mértékben megnehezíti a munkába állást, gettóba zár, csökkenti a mobilitási esélyeket és lehetőségeket.

A kárpátaljaiak és a régióban élő magyar közösség nyelvtudásáról, nyelvismeretének szintjéről több forrásból is rendelkezünk adatokkal. A 2001-es cenzus adataiból például kiderül, hogy Kárpátalja lakosságának jelentős része csak anyanyelvén képes megszólalni. Az egynyelvűek aránya az ukrán nemzetiségűek között volt meszsze a legmagasabb (68,8\%), őket a magyar nemzetiségúek követték (41,3\%). A Kárpátalja területén (is) lebonyolított két legutóbbi cenzus adatai szerint a kárpátaljai lakosság jelentős része nem beszélte az ukrán nyelvet, s még nagyobb volt azoknak az aránya, akik nem beszéltek oroszul, illetve magyarul (1. táblázat). A szociológiai, szociolingvisztikai kutatások adatai szerint a kárpátaljai magyarok államnyelvi és idegen nyelvi nyelvtudása alacsonyabb szintűnek bizonyult, mint a Magyarországgal szomszédos országokban élő más magyar nemzetrészek körében mért nyelvtudásszint (összefoglalóan lásd Beregszászi 2004, Csernicskó 2013: 25-49).

1. táblázat. Kárpátalja lakosságának nyelvtudása az 1989-es és 2001-es népszámlálások adatai alapján (az összlakosság százalékában)

\begin{tabular}{|l|c|c|c|c|c|c|c|c|}
\hline \multirow{2}{*}{ Nyelvek } & \multicolumn{2}{|c|}{$\begin{array}{c}\text { Anyanyelvként } \\
\text { beszélik }\end{array}$} & \multicolumn{2}{c|}{$\begin{array}{c}\text { Másodnyelvként } \\
\text { beszélik }\end{array}$} & \multicolumn{2}{c|}{ Összesen beszélik } & \multicolumn{2}{c|}{ Nem beszélik } \\
\cline { 2 - 9 } & 1989 -ben & 2001-ben & 1989-ben & 2001-ben & 1989-ben & 2001-ben & 1989-ben & 2001-ben \\
\hline Ukrán & 78,10 & 81,00 & 3,86 & 1,57 & 81,96 & 82,57 & 18,04 & 17,43 \\
\hline Magyar & 13,38 & 12,65 & 1,00 & 3,08 & 14,39 & 15,74 & 85,61 & 84,26 \\
\hline Orosz & 4,99 & 2,90 & 53,79 & 2,62 & 58,78 & 5,52 & 41,22 & 94,48 \\
\hline
\end{tabular}

Forrás: Csernicskó (2017: 46)

2016 nyarán - a Nemzetpolitikai Kutatóintézettel, a Lehoczky Tivadar Intézettel, a Momentum Doctorandusszal, az Ungvári Nemzeti Egyetem Szociológia és Szociális Munka Tanszékével, valamint a Kárpáti Közvélemény-kutató Központtal együttműködve - a Hodinka Antal Nyelvészeti Kutatóközpont egy 1212 fős minta bevonásával végzett kérdőíves kutatást Kárpátalján, amely során egyebek mellett az adatközlők nyelvtudására is rákérdeztünk. A Tandem 2016 című szociológiai kutatás kérdőívének kitöltése során arra kértük a megkérdezetteket, hogy - egy meghatározott skála szerint - becsüljék meg, milyen szinten beszélik az egyes nyelveket. A skála a következő volt: anyanyelve (6); jól, helyesen beszél és ír (5); jól beszéli, kisebb hibákkal (4); beszéli, de kifejezésbeli nehézségekkel (3); érti, de nem beszéli (2); nem érti és nem is beszéli (1). 814 fő ukrán, 398 adatközlő pedig magyar nyelven töltötte ki a kérdőívet.

A vizsgálat során magukat elsősorban ukrán nemzetiségűnek valló 721 fő közül 381 (54,7\%) nem ért és nem beszél magyarul. 156 ukrán nemzetiségű adatközlő 


\section{TEMATIKUS TANULMÁNYOK - Kárpátalja társadalma}

$(22,4 \%)$ ért ugyan magyarul, de nem beszéli a nyelvet. 45 ukrán nemzetiségű megkérdezett (6,5\%) anyanyelvi szintű magyar nyelvtudást jelölt a kérdőívben, 115-en pedig $(16,4 \%)$ ennél alacsonyabb fokú nyelvtudást. Az ukrán nemzetiségűek körében a magyar nyelv átlagos ismeretének szintje: „ért, de nem beszél magyarul”. A 455, magát elsősorban magyar nemzetiségúnek valló adatközlő közül mindössze 20 fő $(4,4 \%)$ válaszolta azt a kérdőív vonatkozó kérdésére, hogy nem érti és nem is beszéli Ukrajna államnyelvét. 49 fó $(10,8 \%)$ ért ugyan ukránul, de nem tud megszólalni ezen a nyelven. 57-en (12,6\%) nyilatkoztak úgy a magyar nemzetiségüek körében, hogy anyanyelvi szinten ismerik az ukránt, és 328 adatközlő $(72,2 \%)$ nyilatkozott ennél alacsonyabb szintű nyelvtudásról. A magukat elsősorban magyar nemzetiségűnek vallók körében az államnyelv átlagos ismeretének foka: „jól beszél, kisebb hibákkal".

Ha az Ukrajnában és Kárpátalján máig sajátos helyzetú orosz, illetve az olyan idegen nyelvek ismeretének szintjét vizsgáljuk meg, mint az angol és a német, kiderül, hogy az ukrán alminta statisztikailag szignifikánsan magasabbra értékeli ezen nyelvek ismeretét, mint a magyar alminta (8. ábra). Az idegen nyelvek (angol és német) ismeretének átlagos szintje nagyon alacsony: a kutatásunkban részt vett átlagos adatközlő „ért, de nem beszél” angolul és németül. A kérdőívet ukránul kitöltők között 6,2\%, a magyarul válaszolóknál pedig 13,4\% azoknak az aránya, akik (már) egyáltalán nem értik és nem beszélik a volt Szovjetunió egykor kiemelt helyzetű nyelvét, az oroszt. A megkérdezettek abszolút többsége (az ukránul válaszolók 84,2\%-a, a kérdőívet magyarul kitöltők 71,2\%-a) azonban - önbevallás szerint - rendelkezik valamilyen szintű orosz nyelvtudással.

8. ábra. Az ukrán ( $\mathrm{N}=814)$ és a magyar ( $\mathrm{N}=398)$ alminta idegennyelv-ismerete a Tandem 2016 című kutatás adatai alapján. Hatfokú skálán kapott átlagok: 6: anyanyelve,

1: nem érti és nem is beszéli

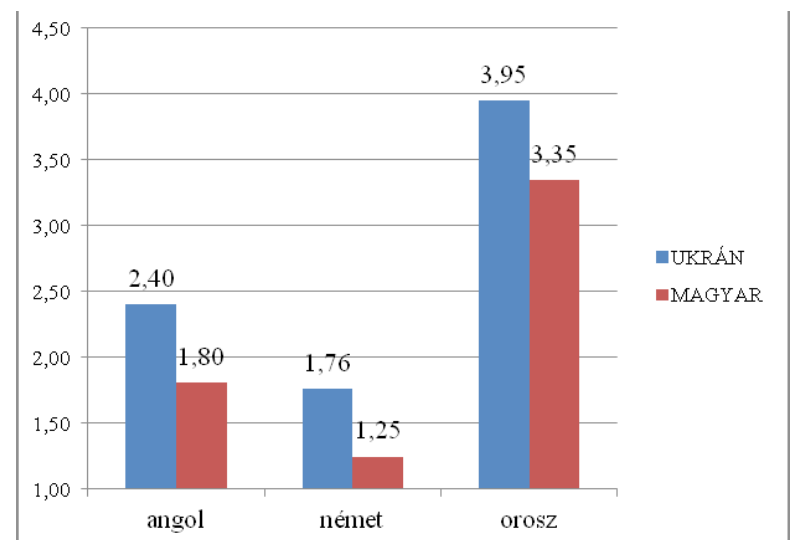

Forrás: A szerző saját szerkesztése 


\section{TEMATIKUS TANULMÁNYOK - Kárpátalja társadalma}

\section{6. Összegzés}

Laitinen és Zabrodskaja (2015: 11-12) szerint a nyelvi tájkép szociolingvisztikai értelmezése tükrözi a társadalmi változásokat, és láthatóvá teszi, milyen forrásokat és hogyan használnak a közösségek a többnyelvű tér kialakítása során. Meggyőződéssel állítják, hogy a nyelvi tájképben bekövetkező változások hasonlóan működnek, mint a nyelvi változások, amelyek soha nem függetlenek a nyelvet használó társadalom, közösség helyzetében, valamint az identitás- a presztízsviszonyokban bekövetkező változásoktól (Laitinen - Zabrodskaja 2015: 12). Rávilágítanak arra, hogy az angol terjedése a világ országainak nyelvi tájképében nem magyarázható egyszerüen a globalizációs folyamatokkal, az elemzés során tekintettel kell lenni a kontextusra, a helyi hatalmi viszonyokra, a kollektív identitás lokális markereire is (Laitinen - Zabrodskaja 2015: 14). Ebben az olvasatban a nyelvi tájképet meghatározzák azok a törvények, rendeletek, melyek felülről (top-down) szabályozzák a nyilvános tér kitöltésének kereteit (Cenoz - Gorter 2006: 68). A fentiekben azonban bemutattuk, hogy a nyelvi jogi szabályozás mellett a nyelvi tájképre közvetlen és lényeges befolyást gyakorolnak a gazdasági folyamatok is. Pavlenko (2017b: 495) ezzel kapcsolatban leszögezi: új jelenségnek tekinthető, hogy a nyelvpolitika már nem az állami hatóságok előjoga, hanem a gazdasági haszon megszerzésének egyik eszközévé vált a globális, multinacionális vállaltok számára éppúgy, mint a magánvállalkozók körében. Legfontosabb megállapítása e témakörben azonban talán az, hogy a nyelv nemcsak a nemzeti büszkeség forrása, nem csupán fontos identitásjelző, hanem a mindennapi gyakorlatokban és hétköznapi diskurzusok során hasznosítható, eladható áruvá vált (Pavlenko 2017b: 495).

Da Silva és Heller (2009) a nyelvpolitikát olyan diskurzív folyamatként írják le, amely a politikai és gazdasági tendenciákban gyökerezik, és ezektől nem függetleníthető. Ehhez az elmélethez kapcsolódva bemutattuk, hogy egy nemzeti kisebbség reagálva a gazdasági környezetben bekövetkezett változásokra, és részben felülírva saját nacionalizmusát - lakóterületének nyelvi tájképét más nyelvű feliratok kihelyezésével alakítja át. Ennek következtében csökken a kisebbségi (a magyar), és nő a más nyelvű (angol, orosz) feliratok aránya; a nemzeti érzelmek és nacionalizmus fölött diadalmaskodik a gazdasági érdek. Így lesz egyre több angol és orosz nyelvű felirat Kárpátalja magyarlakta településein. A turizmus, illetve a turisták, valamint a globális gazdaság és a piaci viszonyok ily módon válnak közvetve a nyelvi tájkép formálóivá, alakítóivá Kárpátalján is (Kallen 2009: 274). Miközben azonban az angol nyelv elsősorban szimbolikus szerepben jelenik meg a vizsgált területen, az orosz nyelv funkcionális szerepben is feltűnik.

Láthattuk azonban azt is, hogy a kárpátaljai magyarok hiányos ukrán, orosz és angol nyelvi ismeretei megnehezítik azt, hogy a közösség könnyen profitáljon Kárpátalja gazdasági, turisztikai felértékelődéséből. A magyar nyelvtudás nyújtotta előnyöket is csak az képes kihasználni, aki anyanyelve mellett más nyelveken is kom- 


\section{TEMATIKUS TANULMÁNYOK - Kárpátalja társadalma}

munikációképes, önmagában a magyar nyelvismeret nem könnyen konvertálható gazdasági erőforrássá. Ez pedig azt jelenti, hogy a nyelvoktatás hatékonyságának növelése nélkül Kárpátalja magyar lakosságának jelentős része a turizmus és a gazdasági pezsgés előnyei helyett annak csupán hátrányait tapasztalhatja.

A magyar nyelvtudás piaci értékére a közeljövőben hatással lesz az is, hogy a magyar kormány támogatásával Kárpátalján több ezren vehetnek részt magyar nyelvtanfolyamokon. Grezsa István, Szabolcs-Szatmár-Bereg megye és Kárpátalja kormánybiztosa egyik 2018 tavaszán tartott előadásában arról számolt be, hogy a budapesti kormányzat által hirdetett ingyenes, 120 órás magyar nyelvtanfolyamok nagyon népszerűek, $\mathrm{s}$,a magyar, mint idegen nyelv lett a legnépszerübb idegen nyelv Kárpátalján, megelőzve az angol nyelvet is". A Budapest által 210 millió forinttal támogatott magyar nyelvtanfolyamokon 2016 májusa és 2017 decembere között közel félszáz helyszínen csaknem 13 ezer fő vett részt (2. táblázat), és a 2018 első negyedévében meghirdetett újabb képzésre közel 4 ezer fő jelentkezett (Grezsa 2018).

2. táblázat. A magyar kormányzat támogatása révén ingyenes, 120 órás magyar mint idegen nyelv tanfolyamok Kárpátalján (2016-2017)

\begin{tabular}{|l|c|c|c|c|}
\hline & $\begin{array}{c}\text { 2016. május - } \\
\text { december }\end{array}$ & $\begin{array}{c}\text { 2016. december - } \\
\text { 2017. április }\end{array}$ & $\begin{array}{c}\text { 2017. április - } \\
\text { június }\end{array}$ & 2017. július - december \\
\hline Helyszín & 52 & 52 & 49 & 44 \\
\hline Oktató & 71 & 117 & 116 & 100 \\
\hline Jelentkezók & 2064 & 3605 & 3197 & 4105 \\
\hline
\end{tabular}

Forrás: Grezsa (2018)

A kárpátaljai szlávok körében tehát fokozatosan nő a magyarul valamilyen szinten beszélők száma, így önmagában a magyar nyelv ismerete még kevésbé jelent majd előnyt, ha nem társul hozzá más nyelvek ismerete is. A magyar egynyelvűség sokkal inkább hátrányt jelent. Amint azt Beregszászi (2002) összefoglalta, a kisebbségeknek nemcsak ahhoz van joguk, hogy identitásukat és anyanyelvüket megőrizzék, hanem ahhoz is, hogy az államnyelv megtanulása révén integrálódjanak és részt vegyenek az adott ország szélesebb társadalmában; ugyanakkor a kisebbségnek érdeke is, hogy az anyanyelv megőrzése mellett elsajátítsa az állam hivatalos nyelvét és (legalább) egy idegen nyelvet.

A fenti elemzés mindemellett arra is rávilágít, hogy önmagában az anyaországnak a nemzeti kisebbség nyelvmegtartását támogató nyelvpolitikája nem lehet sikeres, ha az nem jár együtt gazdaságpolitikai fejlesztésekkel. Kontra (2016: 207) a horvátországi magyarokról írott szavai Kárpátalja vonatkozásában is helytállóak: „Ha azt óhajtjuk, netán akarjuk, hogy a drávaszögi magyarok 50 év múlva is magyarul beszéljenek, akkor ennek olyan gazdasági előfeltételei vannak, amelyek lehetővé 


\section{TEMATIKUS TANULMÁNYOK - Kárpátalja társadalma}

teszik, hogy a magyarok magyarul boldogulhassanak Drávaszögben - 50 év múlva is". Kontra arra is rámutat, hogy az ilyen nyelvpolitika nem utópisztikus vágyálom. Szerinte „A da Silva és Heller (2009) által bemutatott kanadai nyelvpolitika nagyrészt gazdaságpolitika: a kisvárosi frankofón közösségek gazdasági fejlesztésével fordítják vissza az urbanizációt, a kistelepülések kiürülését, tehát a francia ajkúak felszívódását. A politikai tervezés és aktusok tehát nem a nyelv megmentésére irányulnak, hanem a nyelvet beszélő emberek közösségeinek megmentésére" (Kontra 2010: 165).

A magyarországi kormányzat által 2016-ban elindított Egán Ede Kárpátaljai Gazdaságfejlesztési Program (Egán 2018a) - amely a kárpátaljai magyar közösség gazdaságfejlesztési stratégiai tervén alapszik (Egán 2018b) - nagyrészt ezt célozza: a Kárpátalján élő magyar közösség gazdasági pozícióinak javítását, amin keresztül növekszik a magyar nyelv presztízse, javulnak pozíciói, szélesebbé válik használati köre. ${ }^{3}$

A nyelvmegtartást, illetve a kárpátaljai magyar közösség hosszú távú életképességét támogató gazdaságfejlesztési programok kidolgozása és megvalósítása során is figyelembe kell azonban venni, hogy Kárpátalján - ahol a magyar anyanyelvűek a régió összlakosságának alig 13 százalékát teszik ki - sem a hétköznapi élet, sem a vállalkozói lét „nem a nemzeti térbe bezárva, hanem transznacionális térben zajlik, ahol a gazdasági ésszerűség és lehetőségek mentén gyorsan megtörténik az új helyzethez való alkalmazkodás" (Kovály - Erőss - Tátrai 2017: 17-18).

A fentiekben azt mutattuk be, hogy ez a megváltozott gazdasági körülményekhez történő alkalmazkodás folyamatban van Kárpátalján. Ha ehhez hozzáadódnak a magyarországi támogatások, illetve a Kárpátalján hagyományosan jelen lévő határ menti kereskedelem és ingázás (lásd pl. Borbély 2015, Tátrai - Erőss - Kovály 2016, 2017, Pisano - Simonyi 2016), az erősítheti a magyarok és a magyar nyelv pozícióit a régióban. De csak akkor, ha ehhez más nyelvek ismerete is társul.

\section{Irodalom}

Bartha, Cs. - Laihonen, P. - Szabó, T.P. (2015): Nyelvi tájkép kisebbségben és többségben. Egy új kutatási területről. In: Kozmács, I. (szerk.): Kétnyelvűségi szöveggyújtemény. Nyitra Konstantin Filozófus Egyetem Közép-európai Tanulmányok Kara, Nyitra: 213-227.

Bátyi, Sz. (2014): Hévíz: nyelvi tájkép orosz ecsettel. Alkalmazott Nyelvtudomány, XIV, 1-2: 21-34.

${ }^{3}$ Az eltelt idő rövidsége miatt a gazdaságfejlesztési terv hatásairól nem tudunk érdemi következtetéseket levonni. 


\section{TEMATIKUS TANULMÁNYOK - Kárpátalja társadalma}

Bátyi, Sz. (2017): The Impact of Attitudes on Language Retention of Russian as a Foreign Language in Hungary: Some Lessons to be Learnt from Attrition Studies. In: Pfenninger, S.E. - Navracsics, J. (eds.): Future Research Directions for Applied Linguistics. Multilingual Matters, Bristol-Buffalo-Toronto: 265-285.

Belej, L. (2012) Мовний ландшафт Закарпатської області України початку XXI ст. Київ: Інститут мовознавства ім. О.О. Потебні НАН України.

Ben-Rafael, E. - Shohamy, E. - Amara, M. H. - Trumper-Hecht, N. (2006): Linguistic landscape as symbolic construction of the public space: The case of Israel. In: Gorter, D. (ed.): Linguistic landscape: A new approach to multilingualism. Multilingual Matters, Clevedon: 7-30.

Beregszászi, A. (2002): A kárpátaljai magyarság nyelvhasználati sajátosságai a nyelvi tervezés szemszögéből. Kisebbségkutatás, 2: 368-375.

Beregszászi, A. (2004): Idegennyelv-oktatásunk gondjairól és feladatairól szociolingvisztikai nézőpontból. In: Huszti, I. (szerk.): Idegennyelv-oktatás kisebbségi környezetben. Kárpátaljai Magyar Tanárképző Főiskola, Beregszász: 10-20.

Beregszászi, A. (2005): „Csata” a szimbolikus térért, avagy a látható/láthatatlan anyanyelv. In: Beregszászi, A. - Papp, R. (szerk.): Kárpátalja. Társadalomtudományi tanulmányok. MTA Etnikai-nemzeti Kisebbségkutató Intézet - II. Rákóczi Ferenc Kárpátaljai Magyar Főiskola, Budapest-Beregszász: 158-163.

Berghauer, S. (2012): A turizmus mint kitörési pont Kárpátalján(?). Doktori értekezés. Pécsi Tudományegyetem, Pécs

Bever, O. (2010): Linguistic Landscapes of Post-Soviet Ukraine: Multilingualism and Language Policy in Outdoor Media and Advertising. University of Arizona, Tucson

Bever, O. (2015): Linguistic landscapes as multimodal and multilingual phenomena. In: Laitinen, M. -Zabrodskaja, A. (eds.): Dimensions of Sociolinguistics Landscapes in Europe. Materials and Methodological Solutions. Peter Lang, Frankfurt am Main: 233-261.

Bilaniuk, L. (2005): Contested Tongues: Language Politics and Cultural Correction in Ukraine. Cornell University Press, Ithaca, NY and London

Blommaert, J. (2006): Language Policy and National Identity. In: Ricento, T. (ed.): An Introduction to Language Policy: Theory and Method. Blackwell Publishing Ltd., Malden, MA: 238-254.

Blommaert, J. (2010): The Sociolinguistics of Globalization. Cambridge University Press, New York

Borbély, S. (2015): Informális gazdasági stratégiák a magyar-ukrán határvidéken. In: Turai, T. (szerk.): Hármas határok néprajzi értelmezésben. MTA BTK Néprajztudományi Intézet, Budapest: 217-245. 


\section{TEMATIKUS TANULMÁNYOK - Kárpátalja társadalma}

Burdick, C. (2012): Mobility and Language in Place: A Linguistic Landscape of Language Commodification. University of Massachusetts, Amherst

Cabal-Guarro, M. (2017): Is Russian decommodifying in Catalonia? Russian Journal of Linguistics, 21, 3: 605-619.

Cenoz, J. - Gorter, D. (2006): Linguistic landscape and minority languages. International Journal of Multilingualism, 3: 67-80.

Comaroff, J.L. - Comaroff, J. (2009): Ethnicity, Inc. University of Chicago Press, Chicago

Csernicskó, I. (2013): Államok, nyelvek, államnyelvek. Nyelvpolitika a mai Kárpátalja területén (1867-2010). Gondolat Kiadó, Budapest

Csernicskó, I. (2017): Nyelv, nyelvtudás és nyelvhasználat Kárpátalján a Tandem 2016 kutatás adatai alapján. Kisebbségi Szemle, 2, 2: 41-63.

Csernicskó, I. - Laihonen, P. (2016): Hybrid practices meet nation-state language policies: Transcarpathia in the twentieth century and today. Multilingua, 35, 1: $1-30$.

Da Silva, E. - Heller, M. (2009): From protector to producer: The role of the Sate in the discursive shift from minority rights to economic development. Language Policy, 8: 95-116.

Dal Negro, S. (2009): Local policy modeling the linguistic landscape. In: Shohamy, E. -Gorter, D. (eds.): Linguistic landscape. Expanding the scenery. Routledge, New York \& London: 206-218.

Egán (2018a): Egán Ede Kárpátaljai Gazdaságfejlesztési Program. https://www.eganede.com/ (Utolsó letöltés: 2018.07.04.)

Egán (2018b): Egán Ede-terv. A kárpátaljai magyarság gazdaságfejlesztési stratégiai terve. https://www.eganede.com/egan-ede-terv.pdf (Utolsó letöltés: 2018.07.04.)

Fedinec, Cs. - Csernicskó, I. (2016): Az Ukrajnából száműzött Lenin. Európai út a kommunizmus öröksége nélkül? Regio, 24, 1: 73-124.

Feischmidt, M. (2008): The Hungarian Transylvania: Symbolic Reconstruction of Lost Territories. Hungarian Studies, 22, 1-2: 119-133.

Gorter, D. (2006): Further Possibilities for Linguistic Landscape Research. In: Gorter, D. (ed.): Linguistic Landscape: A New Approach to Multilingualism. Multilingual Matters, Clevedon-Buffalo-Toronto: 81-89.

Grezsa, I. (2018): A kárpátaljai magyarságot ért kihívások: egy gondoskodó anyaország válaszreakciói. Elhangzott Makkosjánosiban, 2018. május 2-án az Európai Protestáns Magyar Szabadegyetem Akadémiai Napok című rendezvényén. 


\section{TEMATIKUS TANULMÁNYOK - Kárpátalja társadalma}

Hires-László, K. (2015): Nyelvi tájkép és etnicitás Beregszászon. In: Márku, A. - Hires-László, K. (szerk.): Nyelvoktatás, kétnyelvűség, nyelvi tájkép. Autdor-Shark, Ungvár: 160-185.

Hornberger, N. (2003): English in the global ecology of languages: The value of multilingualism. BESIG Business Issues, 2: 2-6.

House, J. (2003): English as a lingua franca: A threat to multilingualism? Journal of Sociolinguistics, 7, 4: 556-578.

Kallen, J. (2009): Tourism and representation in the Irish linguistic landscape. In: Shohamy, E. -Gorter, D. (eds.): Linguistic landscape: Expanding the scenery. Routledge, London, UK: 270-283.

Karmacsi, Z. (2014a): Település- és utcanevek Kárpátalja magyarlakta településein. In: Beregszászi, A. - Hires-László, K. (szerk.): Meszelt falakon túl: Születésnapi köszöntő kötet Kótyuk István tiszteletére. II. Rákóczi Ferenc Kárpátaljai Magyar Főiskola, Beregszász: 87-98.

Karmacsi, Z. (2014b): Vizuális kétnyelvűség: az új nyelvtörvény adta lehetőségek. In: Bárány, E. - Csernicskó, I. (szerk.): Українсько-угорські міжмовні контакти: минуле $i$ сучасність. Матеріали міжнародної наукової конференції / Az ukrán-magyar nyelvi kapcsolatok múltja és jelene. Nemzetközi tudományos konferencia előadásai. Видавництво В. Падяка, Ungvár:120-131.

Karmacsi, Z. (2017): A nyelvi tájkép változásának egy aspektusa. In: Márku, A. - Tóth, E. (szerk.): Többnyelvüség, regionalitás, nyelvoktatás. Tanulmányok a Hodinka Antal Nyelvészeti Kutatóközpont kutatásaiból III. RIK-U, Ungvár: 54-60.

Kelly-Holmes, H. - Pietikäinen, S. (2014): Commodifying sámi culture in an indigenous tourism site. Journal of Sociolinguistics, 18, 4: 518-538.

Kontra, M. (2010): Hasznos nyelvészet. Fórum Kisebbségkutató Intézet, Somorja

Kontra, M. (2016): Összefoglalás helyett. In: Kontra, M. (szerk.): A magyar nyelv Horvátországban. Gondolat Kiadó - Media Hungarica Művelődési és Tájékoztatási Intézet, Budapest-Eszék: 205-208.

Kovály, K. - Erőss, Á. - Tátrai, P. (2017): „Hát megpróbálunk küzdeni”: átalakuló boldogulási stratégiák Kárpátalján az Euromajdan után. Tér és Társadalom, 31, 2: 3-22.

L'nyavskiy-Ekelund, S. (2016): Ukrainian Language Policy: The Status of Russian in English Language Medium Ukrainian and Russian Newspapers and in the Linguistic Landscape of Four Regions. Master's Thesis. Lund University, Lund

Laihonen, P. - Csernicskó, I. (2017): Kísérlet egy összehasonlító vizsgálatra: a nyelvi tájkép dél-szlovákiai, székelyföldi és kárpátaljai falvakban. Regio, 25, 3: 50-81. 


\section{TEMATIKUS TANULMÁNYOK - Kárpátalja társadalma}

Laitinen, M. - Zabrodskaja, A. (2015): Dimensions and dynamics of sociolinguistic landscapes in Europe. In: Laitinen, M. -Zabrodskaja, A. (eds.): Dimensions of Sociolinguistics Landscapes in Europe. Materials and Methodological Solutions. Peter Lang, Frankfurt am Main: 11-25.

Luliç, E. (2013): Újvidék sétálóutcájának nyelvi tájképe. In: Fedinec, Cs. - Szoták, Sz. (szerk.): Változó világ-változó közösségek a Kárpát-medencében. Határhelyzetek VI. Balassi Intézet Márton Áron Szakkollégium, Budapest: 177-198.

Marten, F.H. - Van Mensel, L. - Gorter, D. (2012): Studying Minority Languages in the Linguistic Landscape. In: Gorter, D. -Marten, H.F. -Van Mensel, L. (eds.): Minority Languages in the Linguistic Landscape. Palgrave Macmillan, Basingstoke:1-15.

Maszenko, L. (2016): Якою мовою говорить патріотизм? Портал мовної політики 2016.11.1. http://language-policy.info/2016/11/yakoyu-movoyu-hovoryt-patriotyzm/ (Utolsó letöltés: 2018.07.04.)

Muth, S. (2015a): 'Ruralscapes' in post-Soviet Transnistria: Ideology and language use on the fringes of a contested space. In: Laitinen, M. -Zabrodskaja, A. (eds.): Dimensions of Sociolinguistics Landscapes in Europe. Materials and Methodological Solutions. Peter Lang., Frankfurt am Main: 199-231.

Muth, S. (2015b): Russian as a commodity: medical tourism and the healthcare industry in post-Soviet Lithuania. International Journal of Bilingual Education and Bilingualism. Retrieved from http://dx.doi.org/10.1080/13670050.2015.1115002

Oliynyk, O. (2013): Особливості співіснування та взаємодії мов у мовному ландшафті міста (на матеріалі знаків Києва). Філологічні науки 1: 223-227.

Pavlenko, A. (2008): Multilingualism in Post-Soviet Countries: Language Revival, Language Removal, and Sociolinguistic Theory. The International Journal of Bilingual Education and Bilingualism, 11, 3-4: 275-314.

Pavlenko, A. (2009): Language Conflict in Post-Soviet Linguistic Landscapes. Journal of Slavic Linguistics, 17, 1-2: 247-274.

Pavlenko, A. (2012): Transgression as the Norm: Russian in Linguistic Landscape of Kyiv, Ukraine. In: Gorter, D. -Marten, H. F. -Van Mensel, L. (eds.): Minority Languages in the Linguistic Landscape. Palgrave Macmillan, Basingstoke: 36-56.

Pavlenko, A. (2017a): Russian-friendly: How Russian became a commodity in Europe and beyond. International Journal of Bilingual Education and Bilingualism, 4. DOI: 10.1080/13670050.2015.1115001

Pavlenko, A. (2017b): Языковые ландшафты и другие социолингвистические методы исследования русского языка за рубежом. Russian Journal of Linguistics, 21, 3: 493-514.

Pisano, J. - Simonyi, A. (2016): Post-Soviet or Eurasian Lands? Rethinking Analytic Categories in the Ukraine-EU and Russia-China Borderlands. In: Bringa, T.- Toje, 


\section{TEMATIKUS TANULMÁNYOK - Kárpátalja társadalma}

H. (eds.): Eurasian Borderlands: Spatializing Borders in the Aftermath of State Collapse. Palgrave Macmillan: 27-58.

Ryazanova-Clarke, L. (2014): Introduction: The Russian Language, Challenged by Globalisation. In: Ryazanova-Clarke, L. (ed.): The Russian Language outside the Nation. Edinburgh University Press, Edinburgh, UK: 1-32.

Rybka, A. (2016): Українська мова й комерція: несумірність чи перспектива. Портал мовної політики 2016.03.28. http://language-policy.info/2016/03/ ukrajinska-mova-j-komertsiya-nesumirnist-chy-perspektyva/ (Utolsó letöltés: 2018.07.04.)

Satinská, L. (2013): Bratilicious Prešburg: Napjaink Pozsonya nyelvi tájképének többnyelvűsége. Fórum Társadalomtudományi Szemle, 15, 2: 89-108.

Shohamy, E. (2015): LL research as expanding language and language policy. Linguistic Landscape, 1, 1/2:152-171.

Simonyi, A. - Pisano, J. (2011): The Social Lives of Borders: Political Economy at the Edge of the European Union. In: De Bardeleben, J. -Hurrelmann, A. (eds.): Transnational Europe. Promise, Paradox, Limits. Palgrave Macmillan, Hampshire, New York: 222-238.

Spolsky, B. (2004): Language Policy. Cambridge University Press, Cambridge

Szoták, Sz. (2013): Nyelvi tájképek az Őrvidéken. In: Fedinec, Cs. - Ilyés, Z. - Simon, A. - Vizi, B. (szerk.): A közép-európaiság dicsérete és kritikája. Kalligram Kiadó, Pozsony: 515-538.

Szoták, Sz. (2017a): Gondolatok nyelv és gazdaság viszonyáról. In: Gróf, A. - Kolláth, A. - Szoták, Sz. (szerk.): Szélrózsa. Termini Egyesület, Budapest: 72-83.

Szoták, Sz. (2017b): Nyelvi tájképek és a gazdaság. In: Benő, A. - Gúti, E. - Juhász, D. - Szoták, Sz. - Terbe, E. - Trócsányi, A. (szerk.): Tudományköziség és magyarságtudomány a nyelvi dimenziók tükrében. Termini Egyesület, Budapest: 135-147.

Tarkanyij, H. (2011): Закарпатська відповідь українському „мовному питанню”. Закарпаття онлайн 2011. március 25. https://zakarpattya.net.ua/News/ 80913- Zakarpatska-vidpovid-ukrainskomu-movnomu-pytanniu- (Utolsó letöltés: 2018.07.04.)

Tátrai, P. - Erőss, Á. - Kovály, K. (2016): Migráció és versengő nemzetpolitikák Kárpátalján az Euromajdan után. Regio, 24,3: 82-110.

Tátrai, P. - Erőss, Á. - Kovály, K. (2017): Kin-state politics stirred by a geopolitical conflict: Hungary's growing activity in post-Euromaidan Transcarpathia, Ukraine. Hungarian Geographical Bulletin, 66, 3: 203-218.

Tóth, E. (2014a): A magyar nyelv megjelenése Badaló és Halábor nyelvi tájképében. Limes - 2014. A II. Rákóczi Ferenc Kárpátaljai Magyar Fóiskola tudományos évkönyve, I. évfolyam. V. Pagyak Kiadója, Ungvár: 57-64. 


\section{TEMATIKUS TANULMÁNYOK - Kárpátalja társadalma}

Tóth, E. (2014b): Mezőgecse község nyelvi tájképe: szociolingvisztikai elemzés. In: Студії з філології та журналістики. Випуск 2. Ужгород: Видавництво ФОП Бреза: 410-412.

Tóth, M. - Csernicskó, I. (2014) Tudományos-gyakorlati kommentár Ukrajnának az állami nyelvpolitika alapjairól szóló törvényéhez. Intermix Kiadó, Ungvár-Budapest

Zabrodskaja, A. (2016): Impact of recent economic and political crises on Estonian language policy. Előadás a The „Crisis” crisis in language policy: A critical look into construction of crisis as a language policy tool címú nemzetközi konferencián 2016. november 28-29-én a finnországi Jyväskyläben 